\title{
Becoming Stories': Creating narrative spaces in initial teacher education
}

\author{
Al Strangeways \\ Charles Darwin University, Australia \\ al.strangeways@cdu.edu.au
}

Keywords: teacher education, teacher identity, narrative, professional learning

\begin{abstract}
Initial Teacher Education (ITE) occurs in a predominantly analytic space, in common with most higher education provision. Creating and legitimising narrative learning community spaces would result in the foregrounding of professional identity formation across the ITE curriculum. The resulting systematic attention to the impact of teacher identity on professional practice will develop teachers who are more resilient and better able to negotiate the theory-to-practice shifts required of classroom-ready teachers (Johnson, Down, Le Cornu, Peters, Sullivan, Pearce \& Hunter, 2010; Hooley, 2007). I present this case for narrative pedagogies by offering two stories from my own journey of increasing commitment to narrative pedagogies. Each story is paired with a preservice teacher narrative from a significant stage in their identity development. And each pair is followed by an analytic interlude that frames the accounts in the literature on narrative ways of knowing and professional identity development. I contend that three things need to occur to establish effective and sustainable narrative learning community spaces. First, teacher educators need to embrace the use of narrative ways of knowing in our pedagogical practice. Second, we need to recognise the embodied complexity of the teaching context, and how narrative can be used to develop preservice teachers' capacity to navigate these 'swampy lowlands' of practice (Schon, 1983, p. 42). Third, we need to teach the skills of narrative writing and interpretation across the ITE curriculum to equip preservice teachers to negotiate their teacher identity and become resilient and creative practitioners. In presenting this series of vignettes about storying in teacher learning, I intend to offer new insights and raise new questions about how narrative can respond to the current needs of initial teacher education (Teacher Education Ministerial Advisory Group, 2014; Sellars, 2014).
\end{abstract}

\section{Introduction}

Teacher narratives are clearly visible in educational research (Goodson, 1990; Clandinin \& Connelly, 2004). Narratives do also operate in teacher education, and have been more frequently used in recent decades: other peoples' stories, in the form of case studies, critical incidents or role-playing, and autobiographical writing have figured in both initial and continuing

1. I use 'becoming' stories to suggest three aspects of the relationship between storying and identity formation: becoming stories are the stories we tell about becoming, charting the ongoing and unfinished process of identity; they are also the stories that we use to construct our becoming or the identities to which we lay claim or aspire (Goodson \& Gill 2014); and they are also the stories we make becoming or attractive by creating a structure (not always to be accepted unconditionally) that helps us manage the untidiness of existence. 
teacher education (McEwan \& Egan, 1995; MacLeod \& Cowieson, 2001; Goodson \& Gill, 2014). Narrative pedagogies have, however, stayed on the periphery of the ITE curriculum, in much the same place that teacher identity is located. The current emphasis on identity in teacher development and aligned research interest in how teachers' beliefs prompt their actions, has not led to any systematic approach to teacher identity development in ITE (Beauchamp \& Thomas, 2009; Murray, Nuttall \& Mitchell, 2008). This may be partly due to the lack of an agreed definition of teacher identity in the literature, which is a product of the postmodern recognition of the complex nature of identity: that it consists of multiple identities, that it changes over time and that it is socially as well as individually constructed (Akkerman \& Meijer, 2011). As Neal Hooley ruminates:

I'm not sure whether teachers feel identified by their 'teacherness' in the same way as others may see themselves as Indigenous . . . or Buddhist . . . (or) as swimmer. . . it may be that teacher identity is still an obscure property, still being constructed in relation to external pressures as the defining feature of the education field. (2007, p. 52)

Hooley's concern about the implications of neglecting teacher identity is echoed in others' perceptions that contemporary reforms in schooling and approaches to teacher 'quality' are undermining the significance of professional identity and leading to the 'erosion of teacher professionalism as it was previously understood,' (Sellars, 2014, p. 25; Darling-Hammond, 1999; Groundwater-Smith \& Mockler, 2009).

In addition to such profession-wide concerns, Hooley also highlights the issue of the classroomreadiness of graduate teachers. He asks whether more methodical narrative enquiry in teacher education programs would resolve this issue, which he noted as prominent in the 2005 Victorian Parliamentary Inquiry, and which remains equally central to the more recent TEMAG report (2014). He suggests that:

Systematic and moral narrative inquiry that is undertaken in a cycle of investigation over long time frames and which develops in reference to the knowledge of others may enable the professional identity of teachers to strengthen in ways that current arrangements do not. (2007, p. 59)

He challenges us to investigate the capacity of narrative approaches to strengthen the relationship between professional identity and practice through the construction of personal knowledge.

In this paper I use stories and analysis to develop Hooley's case for systematically creating and legitimising narrative pedagogies in ITE in order to foreground professional identity formation across the curriculum. I offer insights into the ways narrative epistemologies are central to education pedagogies; I explore how narrative can help teachers navigate the complexity of the classroom and bridge the theory-practice divide; and I suggest we look further at how teaching narrative writing and interpretation skills can equip graduates with the reflexivity and self-efficacy to be confident and resilient classroom-ready teachers.

\section{Method}

My research draws on the traditions of narrative enquiry and critical ethnography and reflects the principles of exploratory practice by emphasising the ethical and epistemological rather than the technical dimensions of practitioner research: 'understanding rather than problem solving' 
(Allwright, 2013, p. 343). Narrative enquiry sits within arts-based research in education (ABER), and is in tune with exploratory practice's post-modern focus on extending understanding by challenging tacit knowledge rather than searching for universal truths (Barone \& Eisner, 1997). ABER blurs the boundaries between the arts and sciences to generate different kinds of insights and to broaden accessibility to people beyond the research academy (CahnmannTaylor, 2008). This fits with my aims to speak to an audience that includes teacher education practitioners and participants, and to foreground the embodied and positioned elements of thought that are neglected in most traditional research processes.

Judith Gill, in her overview of educational research in Australia, emphasises the value of smallscale studies that illuminate 'the close-grained locally embedded work' by grounding our broader understandings in specific educational practices (2004, p. 13). This paper intends to use such local material to fulfil Barone and Eisner's criteria for effective ABER: to illuminate previously unnoticed phenomena, to promote questions, to tightly focus on educationally significant issues, and to be relevant to things beyond itself (1997). The stories are from Alice Springs-based preservice teachers with whom I worked, and were recorded between 2012 and 2015 as part of a longitudinal study of the nature of teacher identity formation and the impact of storying on this development. I have paired their narratives with stories of my own experiences in narrative learning in order to acknowledge the positionedness of my analysis and, by creating resonances between the stories, offer the kinds of open-endedness and depth that best represent the 'embodied complexity' of teaching and learning in preservice teacher education and elsewhere (Davis \& Renert, 2013, p. 3). The analytical interludes which follow each pair frame the accounts by linking them to 'ongoing conversations in the research literature' on narrative ways of knowing and professional identity development (Goodall, 2008, p. 36).

\section{Orientation: narrative ways of knowing and professional identity development}

\section{The English teacher: stories for learning}

I loved teaching English and for fifteen years didn't see myself teaching anything else: I couldn't imagine my life without stories and wanted to open the doors to this world for my high school students. So much of what they learnt in my classes, and how they developed as individuals, seemed to come from their reading and writing of stories. I saw the way their emotions were engaged; the way they could reach towards big ideas from looking closely at the concrete details of the stories we shared; the way a story allowed everyone to have a say in our discussions. Stories have always been at the centre of who I am and who I am becoming; they are how I engage with and make sense of the worlds in which I live. I've been a reader from my earliest memories: short-sighted from reading after bedtime by the light of the orange corridor bulb; in trouble in Maths for having a storybook on my lap under the desk, and avidly exploring the worlds and events of that story instead of plodding my way through the textbook problems towards some elusive right answer. Maths just didn't seem relevant or even engaging: it was too tidy, and didn't respond to the messy, human aspect that was what the world looked like to me.

I've been working in initial teacher education for six years now and am beginning to embrace this different teacher identity. It's one that includes the teaching of Maths, something I really didn't envisage. Three years ago, when I first embarked on the anxious summer of preparation to teach a primary Maths pedagogy unit, I was unprepared for the 'road to Damascus' experience that teaching the unit became. The problem-based pedagogies I discovered and the emphasis on student-generated strategies opened up a world of Maths that was creative and used narrative to probe and develop student-thinking. I realised that many of the diagramming 
techniques l'd used in my English lessons were numerate thinking strategies, and that the boundaries between the arts and sciences are so much more fluid than they appear. And yet still, in this post-Enlightenment world, the primacy of scientific thinking and logical reasoning has meant stories are too often neglected as a significant way of meaning making.

Jessica's hammock: storying and re-storying for identity development

Jessica had come to Alice Springs from country NSW and a career in adventure tourism. She was in the second year of her undergraduate Primary teaching degree when she told me the story of deciding to become a teacher. She had earlier mentioned her long-term involvement with a family from a remote Indigenous community in Central Australia, and the moment she first experienced 'being a teacher.' I asked her to tell me in more detail about that moment.

We were out at the community and it was really cold and wet. Normally when we're out there we go up to the waterhole - there are beautiful waterholes at the top - or we go to the resort and use the pool. But it was a really wet weekend and they had all these old books out there. The school out there had shut down and then it reopened. But during the time that it was shut they sent all the books out for School of the Air. And then when the school opened up again they were just going to throw all the books out. And Bert said, 'No, no, no.' So we managed to keep the books; they're in his shed now. And it was lucky they were there because that weekend it was really wet and the kids - there's Lesley and her little cousin who lives in town that was visiting, Daniel - they just got book after book after book. And I just sat there reading for hours. And then, Lesley, she was five at the time, she started to pick up - like I was just following with my finger - and she started to pick up the words. And it was just blowing me away. I was like, 'Wow, good, good. Good on you'. And it was just this thirst for these books, you know, it was better than TV for these kids. It was so nice to see and to spend that time. I had them both on my lap and yeah, it was just really nice to be able to see that. And then l'd go out every weekend or so and we'd put up a hammock and we'd read books in the hammock and then she'd start telling me, talking to me in language and teaching me ... the kids out there ... they're so full of life, you know, and they're so wanting to learn. I really enjoy that part of it where you just see that lightbulb switch on, that they get it, and that's so rewarding. As all teachers would see l'm sure.

She went on to say that she had told that story and replayed it in her head many times in the three years since:

I have a photo of us in the hammock together sitting above my desk. That's my driving force when I'm studying is that. Being in a beautiful place, like I could just imagine her, how one day if she wanted to be running the tours out there or being a doctor out there ... it just gives me so much hope for her and her cousins and their cousins.

She told me how the story had changed in recent times:

Especially after doing the last unit which was English literacies. You know I thought that was what teaching was, sharing a book with a child, and now I look back on it after knowing more about how to teach children reading and it's not reading to them. They've got to look at the pictures and find their own way through the book, 
especially with all the technology. I mean it was a beautiful moment. But it wasn't, maybe it wasn't teaching as I know it now, so yeah, it's changed into a different story. It hasn't taken away from it at all. It's just that's what I thought, picturing myself as, 'Ah yeah, I could be a teacher, this is wonderful.' And then thinking, 'Well, no, actually.' Now I know that that's not what teaching is about, just sitting around all day reading books. And I think it hasn't taken away from it because they've still got that thirst for knowledge. It's just that books were a novelty to them, and that it's about opening up their minds to things. And so I think that I'm seeing it more broadly, teaching more broadly now.'

\section{Interlude: narrative ways of knowing and professional identity development}

We teach who we are. The educational priorities we select, the teaching strategies we apply, the knowledge we mobilize are all governed by the complex web of values, beliefs, dispositions, experiences and aspirations that make us who we are (Palmer, 1997; Korthagen, 2001). And we use stories not just to express but also to construct our teacher identity (Beauchamp \& Thomas 2009). Psychologist Jerome Bruner locates 'story' as a fundamental structure of human meaning making: both the events of our lives and our identity development can be understood in terms of narrative structure and process (1986). Carol Witherell puts it well when she says, 'Our sense of our lives is embedded in what we make and remake of what happens to us' (1991, p. 89).

It follows then, that being deliberate in our use of stories will better help us understand what we do as teachers because of the interweaving of our - always developing - teacher identity with our practice. Jessica's story, for example, is a significant one for seeing the impact of a 'big story' from one of Measor's 'critical phases' in identity development, the moment of deciding to be a teacher (1985, p. 62). In the embodied specifics of Jessica's interactions with the people, place and events of the story are embedded a complex web of her feelings, values and understandings about teaching, social justice, and the aspirations (for herself and the children) that 'drive' her. These meanings could not be captured in list of abstracted points about her teaching philosophy. Also significant is the way she has remade or 'restoried' the event over the course of her development as a teacher (Clandinin \& Connelly, 1991, p. 259). Her original story of reading in the hammock lost certain meanings (this is teaching) and gained others (perhaps to do with student engagement, or relationships). I'm looking forward to seeing how her story changes again, and how this cycle of restorying the original 'big narrative' will reshape her sense of herself as a teacher and her professional relations.

While narrative ways of knowing have gradually become more accepted in the academy, as teacher educators we need to more fully understand and embrace the centrality of narrative epistemologies to our pedagogical practice. Bruner identifies our post-Enlightenment imbalance:

We devote an enormous amount of pedagogical effort to teaching the methods of science and rational thought. . . Yet we live most of our lives in a world constructed according to the rules and devices of narrative. Surely education could provide richer opportunities than it does for creating the metacognitive sensitivity needed for coping with the world of narrative reality and its competing claims. (1996, p. 149)

In describing the 'competing claims' of the world of 'narrative reality', Bruner identifies the lack of universal truths or simple certainties as narrative reality's key feature. This is because, he asserts, narrative thinking better deals with 'people and their plights', as distinct from the 'physical things' that we use logico-scientific thinking to explore (Bruner, 1996, p. 39). Clandinin 
and Connelly similarly describe the problem of studying this uncertain world of experience as one of 'laying claim to the integrity of the experience itself, fending off its formalist denial through abstraction and the hegemonies of social organisation and structure or reduction into skills, techniques and tactics' (1991, p. 260). Because narrative foregrounds the concrete and human particulars of experience, it is well placed, they suggest, to help us navigate these problems of studying experience. Further, as Ursula Le Guin proposes, because narrative is 'an active encounter with the environment by means of posing options and alternatives and an enlargement of present reality by connecting it to the unverifiable past and the unpredictable future,' it creates a space in which imagination can take us places where reason cannot, getting us 'out of the bind of the eternal present, inventing or hypothesising or pretending or discovering a way that reason can follow into the infinity of options' (1992, p. 44-45).

\section{Complication: the theory-practice gap in the 'ill-structured domain' of teaching}

\section{'B's Story': narratives and complexity}

2011. I shouldn't have been surprised by the response that 'B's Story' (Rorrison, 2008) generated in my group of 80 external-online final year teaching students. I'd taken over the educational partnerships unit at short notice and had been rushing through the set readings to get a bit of a handle on its scope and focus before the semester started. The other readings were all pretty good - effective analyses of the nature of collaborative practice or useful strategies that teachers might use. But reading 'B's Story', the tale of a preservice teacher who struggled to work collaboratively on his placement, made me slow down. Something about the human level of the story, the lack of clear answers, or even a clear dilemma, not only made me slow my own reading of it, but ensured that different elements of the story came to mind at random points over the following days. Characters, dialogue, settings: the concrete business of the story kept popping back into my head and each time sent me off in new directions towards themes or theories or other stories or experiences.

Reading the posts on the online forum, I saw the story working in a similar way for my students. They were writing more and seemed less driven to determine the 'correct' answer to my discussion starters of 'What do you think B did wrong?' and 'What other issues are raised?' They were for the first time using the forum in the way l'd designed it, as a sounding board, a way to socially construct their learning and to draw out for interrogation their own prior understandings and experiences.

As I read the posts I smiled at the way they connected to the humanness and complexity of the situation, and at the way their insights both stemmed from and challenged their previous experiences and knowledge. I would nod, 'Yes,' when I read, 'I'm looking at things in a different way now,' or 'I really felt for B's students/or B/or B's mentor,' or even, 'The more I reflect about it the more complicated it seems.' The story got them thinking in different ways, and brought out the personal perspectives, beliefs and assumptions they brought to teaching. I really felt I was getting to know them. The story also left them wondering: they had responded to it as if it was a lived experience and they saw there were no simple answers to be found: I wondered at the future times they would recall the unfinished complexities of 'B's Story', and the impact their response to it would have on their development. The experience reminded me of so many of the things I love about narratives: the sneaky way they bypass the 'policeman' of our tacit knowledge to make us consider the previously unthinkable. The way they stick in our minds. And the glorious messiness and open-endedness of the situations they allow us to enter and experience. As messy as life, but at one remove, offering us time and safety in which to explore its complexities. 
I wondered what the effect would be if we used such rich stories or cases more centrally in every unit of our teaching degrees. Would they offer similar kinds of 'experiential' learning to those so valued by preservice teachers in their placements, but from a setting outside of the school placement and the traditional mentoring dynamic? In my work with preservice teachers and mentors, l've always felt how much we all expect from the placement experience. It's where theory gets put into practice. While placement is the lynch pin of any teacher education degree, often the pressure of expectation has seemed to be excessive and overly dependent on the mentoring skills of individual mentor teachers and the mentoring culture of the school. Can interpreting and writing rich 'stories of experience' take some of this pressure off placement by creating a new space within the university where practice is the foundation to which theory is then applied?

\section{Jane's first day: negotiating the 'ill-structured' domain of teaching}

Born in Alice Springs and educated at the local Catholic high school, Jane had chosen to stay in Central Australia to undertake her teaching degree in secondary English and History. At the time of this interview, she had completed two years of content units and one year of education units, including two of her four required school placements. She described how her first placement confirmed her choice of high school teaching as a profession.

Walking into the school was first off a really big eye opener because it was totally different to Our Lady of the Sacred Heart. My personal beliefs are of doing really well and learning everything that you can, and you've got kids who were like,'l don't want to be here'. I was just, 'What the hell? You should want to learn!' I think that actually contributed to it - that slap in the face. I felt comfortable there, even though I felt uncomfortable because I was aware of how I was different to the students. But I felt comfortable there, just as a general vibe. It just felt normal. And that feeling just kind of stayed with me.

And then when I taught my first class it went really well and I was thinking, 'Yes, this is it.' Taught the same lesson to another class and it went terribly and I still felt that it was right. And I think I felt that way because I could see the difference between the two classes, thinking I shouldn't have done this or that. But I didn't beat myself up about it. It was just, 'OK, let's pick ourselves up, move on and what do we do next?' And I didn't actually mind that they were cheeky kids. Because they made jokes about what we were learning about and you can just fold that in. And I actually wonder sometimes if I'd feel that way if I walked into a primary school. I don't think I would have. I think I would have gone, 'Oh gosh, I think I've just made a terrible mistake; the last two years have been a total waste.' Interesting that high school, middle school, did it for me. I just felt I slipped right in. It could have been their cynicism, but it could also have been just the unexpected. I like things in order, and then you just walk into a classroom and it doesn't happen and I think I need that and I really like it. In a perverse way.

That's made me think of this one lesson I taught on my second placement where things changed: I was structured and had organised this lesson and had everything set out and when I got in there my lesson totally changed. I just did things backwards and I did this instead of that and we did a group discussion instead of private reading and that disorder came through. I think I can be disordered because I have order and I think if I was disorganised in my planning, being disorganised in my 
lesson just wouldn't have been ok. It would have just gone totally all over the place but because I knew my lesson, I knew what I wanted to achieve, I could just pretty much throw it out the window and go, 'We're going to do something else. Because you guys want to talk, we're going to talk'. And probably, I didn't get to experience that so much on my first placement but I think it was there in the back of my mind, or in the classroom, but I hadn't picked up on it. Having one class that went really well according to the plan and another class where I had to change things and because I didn't change things it didn't go well. So like a Yin and Yang almost.

Towards the end of the interview she linked this to her own experiences of learning:

I wrote a philosophy at the start of the year and I went, you know, 'Without looking at it I'm going to try and write another one and just see how different or how much they're the same. I'll do it before the interview'. Didn't happen because I couldn't quite set it in stone, what I wanted to write. I sometimes feel like my philosophy should be a drawing. Like this is how it happens. That might even be a better idea. Draw it and then kind of have a brief description underneath saying this is what it is. This is where it all goes, and how it all moves. Not linear. That's something that's really struck me this last year. Prior to that my learning was just all linear. This is what you do, you write an essay. But this last year it's been, nothing works in a straight line. There shouldn't even be straight lines. They're for driving. They're for the sides of the roads, just so you can't park here. That's not what this is. Your learning shouldn't be linear, your teaching shouldn't be linear and your experience shouldn't be linear. Because it all interconnects. But it also shouldn't be circular. Because it doesn't necessarily all flow in that one direction. Sometimes it flows backwards. I've certainly focused on it a lot in my reflective writing. I've really pulled up this word linear all the time, probably to the point that it's starting to get over used. But I feel like it's very, very important. I kind of look at everything as if it should be everywhere, connected in some way, but everywhere. And there's no chronological order to it or no set way.

\section{Interlude: the theory-practice gap and the bridge of narrative}

Classrooms are complex places. We need to recognise the complexity of the 'ill-structured domain' of the teaching context and the ways narrative can be used to help preservice teachers cope with that complexity (Spiro, Coulson, Feltovich, \& Anderson, 1989, p. 498). Cognitive psychologists Spiro et al. define the 'ill-structuredness' of a domain as when 'many concepts, interacting contextually, are pertinent in the typical case of knowledge application and .... (when) their patterns of combination are inconsistent across case applications of the same type' (p. 498). They point out that effective methods for introductory level learning, such as 'compartmentalizing knowledge, presenting clear instances (and not many pertinent exceptions)' (p. 498), often interfere with the kinds of advanced knowledge acquisition that are needed to respond well in the messy uncertainties of a real context. This issue has also been conceptualised as one of a gap between 'theory and practice', where the clear certainties of the theoretical world are challenged by the uncertainties and conflicts of the practical world and result in professional practice remaining unchanged by new knowledge (Dewey, 1929; Argyris \& Schon, 1974).

This theory-practice disjunction is mirrored in the dualism of linguistic propositional knowledge ('knowing that') and experiential knowledge ('knowing how' and 'knowing what') (Dohn, 2007). 
Propositional knowledge offers the kinds of linear thinking and clear certainties that Jane saw as insufficient to address the complex and often paradoxical nature of the teaching setting and teachers' work. It's telling, Jane's use of 'and' rather than 'but' in her comment: 'I like things in order, and then you just walk into a classroom and it doesn't happen.' The conjunction choice suggests a lack of opposition between these two apparent polarities of order and disorder, between the 'high hard ground of theory' and the 'swampy lowlands of practice' Schon so vividly evokes (1983, p. 42). Just as the teaching philosophy that Jessica's story presents cannot be as effectively represented in a list, so Jane sees her post-placement philosophy as unable to be articulated in linear form. And while narratives may seem linear at first glance (we usually read them from start to finish), the meaning they build in our minds is spatial and rhizomatic in contrast to the linear structures of logico-scientific thinking (Bruner, 1986).

'Teaching isn't telling,' always seemed to me to need the caveat, ' . . . unless it's telling stories', which itself is a very different kind of 'telling' to that which imparts propositional knowledge. And of course outside of educational institutions, stories are recognised as a key medium of the transmission of cultural norms, beliefs and knowledges (Bruner, 1986). 'B's Story' got me thinking about the opportunities we miss in teacher education to establish a meaningful 'back and forth' between the theory and the practice: between asking our students to think like learners at the university and asking them to think like teachers in the classroom; and between asking them to think like 'rule-based beginners' who rely on 'analytic rationality', and asking them to think like experts, using the type of 'context-dependent knowledge and experience [that] are at the very heart of expert activity' (Flyvjberg, 2004, p. 421).

Interpreting and writing narratives of professional experience offers a space and a community of learners in which preservice teachers can approach teaching experiences both as professionals, whose voice and personal experience is valued, and also as beginners, using the community to safely encounter and learn to negotiate the uncertainties of educational contexts and issues. Because narratives produce 'likelihood' not certainty, they direct our attention to the unique concrete details and discontinuities of a 'real' situation, and so move us from purely conceptual ways of understanding to emphasising the perceptual dimension of our knowing (Polkinghorne, 1988, p. 75). And because narrative emphasises these perceptual ways of knowing, when we interpret and discuss stories - whether external 'cases' or autobiographical writing - we develop the conditional and reflexive thinking that are key skills required in expert professional practice (Levin, 1995).

Preservice and neophyte teachers are often overwhelmed by the complex reality of the classroom: they back away from its uncertainties by grasping at the straws of magic bullets and one-size-fits-all solutions; and they see it as a failure of theory when the theory doesn't provide them with the certainty they desire. This disposition is a natural tendency of the technical rationality of beginners and a result of the methods of introductory learning and as educators we need to address ourselves to modifying it during ITE. We need to find ways to use narrative pedagogies to create a learning space that is beyond the rule-based understandings of beginners and before the contextual-knowledge based fluency of experts if we are to respond to the need to develop 'classroom ready' teachers who are ready to deal with classroom complexities. Offering narrative as a systematic mode of learning across the curriculum would ensure that the complexities of practice are addressed even in the beginning stages of learning. The ubiquity of this mode would also, then, make it meaningful to explicitly teach the skills of narrative writing and interpretation. By fostering the development of 'narrative reasoning skills', Sara Worth suggests, we build imaginative and moral dimensions of knowledge is 'more than just propositional' (Worth, 2005, p. 19). These creative, relational and ethical dimensions are at the heart of teacher professional practice. 


\section{Resolution: Implications}

If we integrated a suite of narrative pedagogies - such as critical incident analysis casediscussion, narrative-reflection, and co-constructed stories - throughout the ITE curriculum, we would foreground teacher identity development and illuminate the complexity of the professional setting (Bolton, 2014; Levin, 1995; Clandinin \& Connelly, 1991; Measor, 1985). By doing this, we would address the 'tension of dissent' that exists between practice and theory in every ITE curriculum (Hooley, 2007, p. 55). To integrate narrative successfully, however, we need to be mindful of two related issues: the difficulty of systematically analysing narrative thinking, and the need to ensure that personalised narratives are not 'uncoupled from the wider picture' of the socio-political 'structures and systems' in which teachers' work takes place (Goodson, 1997, p. 111).

Bruner proposes that a key reason narrative epistemologies have not taken any systematic hold in the academy is because narrative construals of reality are

surprisingly difficult to dissect ... (being) too ubiquitous, their construction too habitual or automatic to be accessible to easy inspection. We live in a sea of stories, and like the fish who (according to the proverb) will be the last to discover water, we have our own difficulties grasping what it is like to swim in stories. (1996, p. 147)

Approaching narratives metacognitively, he suggests, is one way to arouse us from 'this peculiar kind of unconsciousness of the automatic (and) ubiquitous.' This would mean that discussions about 'who we are' and 'what we know' are transposed to discussions about 'how we know' in order to 'provide a reasoned base for the interpersonal negotiation of meanings' (1996, p. 147). Such metacognitive practices could be achieved through developing the narrative writing and interpretation skills of preservice teachers, by allowing them to recognise the 'craftedness' of their and others' narrative constructions of identity and reality.

By taking a critical and metacognitive approach to narrative practices, we would also address the concern that for personal narratives to produce credible knowledge, that knowledge must 'develop in relation to the knowledge of others' (Hooley, 2007, p. 56). In order to build relationships to knowledge beyond the personal, narratives need to be created and interpreted with the explicit application of theory, with attention to 'politically situated perspectives', and in a collaborative and facilitated community of learners (Griffiths, 1994, p. 76; MacLeod \& Cowieson, 2001). As David Thomas suggests, 'If there are no innocent texts, there are no privileged interpretations; although as readers we can benefit by the guidance of a thoughtful leader to take us through the narrative maze (Thomas, 1993, p. 244). We need to position the writing and interpretation of narratives in their socio-political and theoretical context if we want narrative epistemologies to engage critically with the 'vernacular of power - the ways of talking and knowing which then become the prerogative of managers and administrators and academics' and so challenge the discourses or 'coercive narratives' that seek to narrow and technicise our profession (Goodson, 1997, p. 117; McEwan, 1997, p. 85).

\section{Coda: a continuing story}

2015. I've just finished my first series of "caselearning'2 workshops in Alice Springs and a colleague and I are beginning to analyse the data from this pilot project, putting together a

2. My colleague, Lisa, and I use the term 'caselearning' to cover the pedagogies of both case-writing and case-interpretation for learning. The first is a form of contextualised autobiographical writing (Bolton, 2014; Goodson \& Gill, 2014), the latter a modification of case-method learning (Levin, 1995). 
conference presentation, and a project report for the funders of our seed grant (Papatraianou \& Strangeways, 2015). The main series of workshops was with my Alice-based preservice teachers but I also spent a day working with a group of Department of Education teachers who are writing cases about their school-based action research cycles. I'm amazed by how far we've all come in one semester. We have templates for case-writing and case-interpretation, an interactive website to house the cases and their interpretations, and many people have written thought-provoking narratives and are looking forward to writing more. Narrative writing was an intimidating challenge for some. 'I haven't done this since high school', said one of the Graduate Diploma students; 'I just know that anything I write will be terrible,' said a senior teacher from primary school. I surprised myself by how long it took me to put a stop to our discussions about cases and writing, and actually get people putting pen to paper. I had done this every day as an English teacher, with all sorts of recalcitrant students! Why on earth was it now so hard? Once we'd started, however, the results of their writing and analysing seemed at times close to transformative. 'I love how it forces you to step outside yourself,' said one, 'And each time I go back to read what I've written, I see it from a different angle, or different bits stand out'; 'It's great to do reflection properly and do it with a structure,' said another; 'I never thought l'd be one to write a case, and enjoy it,' said another. I'm looking forward to where we go next, to developing the caselearning resource and framework in order to explicitly teach narrative ways of thinking. If it works, we'll be one step closer to re-positioning storying and professional identity development at the centre of teacher professional learning.

\section{References}

Akkerman, S.F., \& Meijer, P.C. (2011). A dialogical approach to conceptualizing teacher identity. Teaching and Teacher Education, 27(2), 308-319.

Allwright, D. (2013). Developing Principles for Practitioner Research: The case of Exploratory Practice. The Modern Language Journal, 89(3), 353-366

Argyris, C., \& Schon, D. (1974). Theory in Practice: increasing professional effectiveness. San Francisco: Jossey-Bass

Barone, T., \& Eisner, E.W. (1997). Arts-based education research. In R.M. Jaeger, \& T. Barone (Eds.), Complementary methods for research in education. (pp 95-109). Washington, DC: American Educational Research Association

Beauchamp, C., \& Thomas, L. (2009). Understanding teacher identity: an overview of issues in the literature and implications for teacher education. Cambridge Journal of Education, 39(2), 175-189

Bolton, G. (2014). Reflective practice: Writing and professional development. London: SAGE

Bruner, J. (1986). Actual Minds, Possible Worlds. Cambridge, MA: Harvard University Press

Bruner, J. (1996). The Culture of Education. Cambridge, MA:Harvard University Press.

Cahnmann-Taylor, M., \& Siegesmund, R. (2008). Arts-based research in education: Foundations for practice. New York: Routledge.

Clandinin, D.J., \& Connelly, F.M. (2004). Narrative inquiry: Experience and story in qualitative research. San Francisco: Jossey-Bass.

Clandininin, D., J. \& Connelly, F.M. Narrative and story in practice and research. In C. Witherell \& N. Noddings (Eds.), Stories Lives Tell: Narrative and Dialogue in Education (pp. 259-281). New York: Teachers College.

Darling-Hammond, L. (1999). Reshaping teacher policy, preparation and practice: Influences on the National Board for Teaching Professional Standards. Washington, DC: AACTE Publications 
Davis, B., \& Renert, M. (2013). The math teachers know: Profound understanding of emergent mathematics. New York \& London: Routledge

Dewey, J. (1929). The quest for certainty: A study of the relation of knowledge and action. New York: Monton, Balch \& Co. Accessed November $12^{\text {th }} 2015$ from: https://archive.org/stream/ questforcertaint032529mbp\#page/n27/mode/2up

Dohn, N.B. (2000). Knowledge in practice. Network for Non-Scholastic Learning (Working Papers, No. 1). Denmark: Aarhus Universitet. Accessed $4^{\text {th }}$ November 2015 from: https://telearn.archivesouvertes.fr/hal-00190360/

Flyvjberg, B. (2004). Five misunderstandings about case-study research. In C. Seale, G. Gobo, J.F. Gubrium, \& D. Silverman (Eds.), Qualitative research practice (pp 420-434). London: Sage

Gill, J. (2004). Having our work cut out! Reflections on the Australian Association for Research in Education and the current state of Australian education research. Australian Educational Researcher, 31(1), 1-14.

Goodall, H.L. (2008). Writing qualitative inquiry: Self, stories and academic life. Walnut Creek, CA: Left Coast Press, Inc.

Goodson, I.F. (Ed.). (1990). Studying teachers' lives. London: Routledge.

Goodson, I.F. (1997). Representing teachers. Teaching and Teacher Education 13(1), 111-117

Goodson, I., \& Gill., S. (2014). Critical narrative as pedagogy. New York \& London: Bloomsbury.

Griffiths, M. (1994). Autobiography, feminism and the practice of action research. Educational Action Research, 2(1), 71-82

Groundwater-Smith, S., \& Mockler, N. (2009). Teacher professional learning in an age of compliance: Mind the gap. Dordrecht: Springer Netherlands.

Hooley, N. (2007). Establishing Professional Identity: Narrative as Curriculum for Pre-Service Teacher Education. Australian Journal of Teacher Education, 32(1), 49-60.

Johnson, B., Down, B., Le Cornu, R., Peters, J., Sullivan, A.M., Pearce, J., \& Hunter, J. (2010). Conditions that support early career teacher resilience. Refereed paper presented at the Australian Teacher Education Association Conference, 4th-7th July, Townsville, Qld. Accessed October 20 2015 from: http://www.atea.edu.au/ConfPapers/2010/Refereed/A\%20Sullivan.doc

Korthagen, F. (2001, April). Linking practice and theory: The pedagogy of realistic teacher education. Paper presented at the Annual Meeting of the American Educational Research Association, Seattle. Accessed November $10^{\text {th }} 2015$ from: http://citeseerx.ist.psu.edu/viewdoc/ download?doi=10.1.1.92.1562\&rep=rep1\&type=pdf

Le Guin, U. (1992). Some thoughts on narrative. In Dancing at the Edge of the World. Glasgow: Paladin-HarperCollins.

Levin, B. B. (1995). Using the case method in teacher education: The role of discussion and experience in teachers' thinking about cases. Teaching and Teacher Education, 11, 63-79

McLeod, D.M.\& Cowieson, A.R. (2001). Discovering credit where credit is due: using autobiographical writing as a tool for voicing growth. Teachers and Teaching, 7(3), 239-256

McEwan, H., \& Egan, K.. (Eds.) (1995). Narrative in Teaching, Learning, and Research. New York: Teachers College Press.

Measor, L. (1985). Critical incidents in the classroom: Identities, choices and careers. In S.J. Ball \& I.F. Goodson (Eds.), Teachers Lives and Careers. London: The Falmer Press. 
Murray, S., Nuttall, J., \& Mitchell, J. (2008). Research into initial teacher education in Australia: A survey of the literature 1995-2004. Teaching and Teacher Education 24(1), 225-239

Palmer, P.J. (1997). The heart of a teacher: Identity and integrity in teaching. Change: The Magazine of Higher Learning, 29(6), 14-21.

Papatraianou. L., Strangeways, A., \& Ford, J. (2015, November). Case-based learning for classroomready teachers: building self-efficacy and resilience through narrative pedagogy. Paper presented at the Australian Association for Research in Education Conference, Fremantle.

Polkinghorne, D.E. (1988). Narrative knowing and the human sciences. Albany, NY: SUNY Press.

Rorrison, D. (2008). Jumping through spinning hoops: Stories of the middle school and secondary practicum. Melbourne VIC: Cengage Learning

Schon, D.A. (1983). The reflective practitioner: How professionals think in action. New York: Basic Books Inc.

Sellars, M. (2014). Reflective practice for teachers. London: SAGE.

Spiro, R.J., Coulson, R.L., Feltovich, P.J., \& Anderson, D.K. (1989). Cognitive flexibility theory: Advanced knowledge acquisition in ill-structured domains. In S. Vosniadou \& A. Ortony (Eds), The Tenth annual conference of the Cognitive Science Society (pp 498-531). Hillsdale, New Jersey: Lawrence Erlbaum Associates, Inc.

Teacher Education Ministerial Advisory Group. (2014). Action now: Classroom ready teachers. Accessed August 162015 from http://www.studentsfirst.gov.au/ teacher-education-ministerial-advisory-group.

Thomas, D. (1993). Treasonable or trustworthy text: Reflections on teacher narrative studies. Journals of Education for Teaching, 19(4), 231-249.

Witherell, C. (1991). The self in narrative: A journey into paradox. In C. Witherell \& N. Noddings (Eds.), Stories Lives Tell: Narrative and Dialogue in Education (pp. 83-95). New York: Teachers College Press.

Worth, S.E., (2005). Narrative knowledge: Knowing through storytelling. MIT4: Fourth Media in Transition Conference. Cambridge, MA, May 6-8. Retrieved 4 November 2015 from: http://web.mit.edu/ comm-forum/mit4/papers/worth.pdf. 